\title{
Spatial variations of sea-level rise and impacts: An application of DIVA
}

Sally Brown ${ }^{1}$ Robert J Nicholls ${ }^{1}$, Jason A Lowe ${ }^{2}$, Jochen Hinkel ${ }^{3,4}$

1. Faculty of Engineering and the Environment and Tyndall Centre for Climate Change Research, University of Southampton, University Road, Highfield, Southampton. SO17 1BJ. UK.

Phone: +44 (0)2380 594796

Fax: +44 (0)2380 677519

Corresponding author email: sb20@soton.ac.uk

2. Met Office Hadley Centre (Reading Unit), Department of Meteorology, University of Reading, Earley Gate, Reading. RG6 6AH. UK.

3. Global Climate Forum e.V. (GCF), Adaptation and Social Learning, Neue Promenade 6, 10178 Berlin, Germany.

4. Potsdam Institute for Climate Impact Research (PIK), Transdisciplinary Concepts and Methods, P.O. Box 601203, 14412 Potsdam, Germany. 
Abstract: Due to complexities of creating sea-level rise scenarios, impacts of climate-induced sealevel rise are often produced from a limited number of models assuming a global uniform rise in sea level. A greater number of models, including those with a pattern reflecting regional variations would help to assure reliability and a range of projections, indicating where models agree and disagree. This paper determines how nine new patterned-scaled sea-level rise scenarios (plus the uniform and patterned ensemble mean rises) influence global and regional coastal impacts (wetland loss, dry land loss due to erosion and the expected number of people flooded per year by extreme sea levels).

The DIVA coastal impacts model was used under an A1B scenario, and assumed defences were not upgraded as conditions evolve. For seven out of nine climate models, impacts occurred at a proportional rate to global sea-level rise. For the remaining two models, higher than average rise in sea level was projected in northern latitudes or around populated coasts thus skewing global impact projections compared with the ensemble global mean. Regional variability in impacts were compared using the ensemble mean uniform and patterned scenarios: The largest relative difference in impacts occurred around the Mediterranean coast, and the largest absolute differences around low-lying populated coasts, such as south, south-east and east Asia. Uniform projections of sea-level rise impacts remain a useful method to determine global impacts, but improved regional scale models of sea-level rise, particularly around semi-enclosed seas and densely populated lowlying coasts will provide improved regional impact projections and a characterisation of their uncertainties.

Keywords: Sea-level rise, impacts, pattern-scaling, variability, coastal flooding, coastal erosion, wetland loss

Abbreviations:

CIS

CMIP3

DIVA

AOGCM

AR4

ASMITA

GIA

GLOBE
Commonwealth of Independent States

Coupled Model Intercomparison Project.

Dynamic Interactive Vulnerability Assessment

Atmosphere-Ocean General Circulation Model

Fourth Assessment Report

Aggregated Scale Morphological Interaction between a

Tidal basin and the Adjacent coast

Glacial isostatic adjustment

Global Land One km Base Elevation Project 


\section{Introduction}

Coastal environments house important ecosystems and densely populated regions. Many of these people rely directly on coasts for their livelihoods and well-being (Nicholls et al. 2007). With rising sea levels, it is important to understand what, where and who could be affected over the coming century, and when this will happen, in order to manage change effectively. Scientists are confident that globally mean sea levels are rising and broadly envisage where potential impacts may occur (Nicholls and Cazenave 2010). However they are less certain about the magnitude and spatial distribution of rise, and subsequent impacts.

The Intergovernmental Panel on Climate Change's Fourth Assessment Report (AR4) expressed a likely range in temperature of $1.1^{\circ} \mathrm{C}$ to $6.4^{\circ} \mathrm{C}$ from $1980-1999$ to 2090-2099 (depending on emissions scenario), associated with a rise in global mean sea-level of between $0.18 \mathrm{~m}$ and $0.59 \mathrm{~m}$, with a possible increase to $0.76 \mathrm{~m}$ if rapid ice sheet discharge continued (Meehl et al. 2007). Since then, uniform sea-level rise projections have ranged from $0.5 \mathrm{~m}$ to $2.41 \mathrm{~m}$ of rise per century (summarised in Nicholls et al. 2010; 2011). To date, most global impact studies have concentrated on the effects of uniform sea-level rise often from a single model (e.g. Nicholls 2004; Nicholls et al. 2011), with a few exceptions (e.g. Pardaens et al. 2011; Hinkel et al. submitted) as this is a simple, quick and easy method. However as oceanic temperatures, salinity, mass distribution and largescale ice melt change, this creates regional variations. Subsequently patterned sealevel rise scenarios have emerged, reflecting areas of higher and lower rise or fall. Although more time consuming and computationally more expensive to generate, patterned scenarios compared with uniform scenarios of sea-level rise are generally considered more realistic of present observations.

This paper asks 'How do patterned scenarios of sea-level rise influence the distribution of impacts?' Outputs will act as a sensitivity analysis, indicating where models agree or disagree. Thus outcomes will be useful for modelers and will help characterise uncertainty, pointing towards global regions where further research is required in terms of understanding sea-level rise patterns and subsequent impacts. 
To achieve this, using a consistent set of socio-economic and adaptation assumptions, this paper (1) generates nine new pattern-scaled sea-level rise scenarios (plus their ensemble mean) and discusses the magnitude of rise and the spatial differences; and (2) investigates the effect of spatial variations of sea-level rise on global and regional impacts.

\section{Methodology: The DIVA model}

Three impact parameters are assessed:

(1) Coastal wetland loss;

(2) Dry land loss due to erosion; and

(3) Expected number of people flooded per year.

These were examined by using the Dynamic Interactive Vulnerability Assessment (DIVA) model (version 2.0.4, GLOBE $1 \mathrm{~km}$ resolution topographic dataset) (Vafeidis et al. 2008; Hinkel and Klein 2009), an integrated bio-geophysical coastal systems model driven by climate change and socio-economic development. The model downscales the sea-level rise scenarios taking account of isostatic adjustment based on Peltier (2000a,b) and natural subsidence in 200 of the world's river deltas assumed as $2 \mathrm{~mm} / \mathrm{yr}$. Flooding of the coastal zone is caused by sea-level rise and associated extreme water levels, where the return period of extreme sea levels is reduced by displacing extreme water levels upwards with a rising sea level.

Loss of coastal wetlands (mangroves, saltwater marsh, freshwater marsh, coastal forest and high/low unvegetated wetlands) are calculated through the interaction of the rate of sea-level rise, tidal range, sediment supply and lateral accommodation space (McFadden et al. 2007). Dry land loss by erosion was assessed for erodible sandy coasts (estimated at about $11 \%$ globally) using the methodology described in Hinkel et al. (accepted), which applies the Bruun Rule (e.g. Zhang et al. 2004) for direct erosion and a simplified version of the ASMITA model (van Goor et al. 2003) for indirect erosion that occurs near systems of tidal basins. 
The expected number of people flooded per year by extreme sea levels is the product of population and the extreme water level probability distribution. This is determined by the population living in the coastal flood hazard zone (below the 1:1,000 year surge level) and the water level exceedance curve, including the effect of any adaptive measures such as dikes. Using population density in 1995 based on CIESIN et al (2000), the model assumed coastal population growth proportional to the SRES A1B scenario.

Defences (sea and river dikes) for the year 1995 were estimated using a demand for safety function - where higher population densities attract greater defence standards. These defences are assumed to be constant over time (that is, there is no additional adaptation). Further information about the DIVA model is in the Supplementary Material.

\section{Input scenarios}

\subsection{Climate scenarios}

\subsubsection{Generating scenarios}

The simple climate model, MAGICC 4.2 (Meehl et al. 2007; Raper and Cubasch 1996) was tuned to global average surface temperature and radiative flux at the top of the atmosphere with a default of $3.71 \mathrm{~W} / \mathrm{m}^{2}$ for $2 \mathrm{xCO}_{2}$ for an $\mathrm{A} 1 \mathrm{~B}$ scenario, as described in Osborn et al (submitted). Manning et al (2010) found present carbon dioxide emissions (until 2009) fell between the A1B and A1FI SRES scenarios. Thus, if an A1FI scenario is followed rather than A1B, rates of sealevel rise may be higher.

Scenarios were created from thermal expansion and land-based ice melt contributions (ice sheets, ice caps and glaciers) following the methodology described in Meehl et al. (2007). Linear pattern scaling (indicating areas of lower than, and greater than average sea-level change) was applied by multiplying the 2080s pattern of thermal expansion (from a $1^{\circ} \times 1^{\circ}$ grid) by a time series of global 
mean thermal expansion, following van Vuuren et al. (2007). Uniform ice melt was assumed using central estimates of model parameters. For ice caps and glaciers, area-volume scaling was undertaken, and for ice sheets, a surface mass balance equation was applied using AOGCM outputs of ice sheet dynamics from Gregory and Huybrechts (2006). These were summed to create total sea-level rise for nine patterned CMIP3 models (GFDL-CM2.0, GFDL-CM2.1, GISS-EH, GISS-ER, MIROC 3.2 (medres), ECHAM5-MPI-OM, MRI-CGCM2.3.2, UKMO-HadCM3, CGCM3 (T47)), plus the multi-model ensemble mean patterned and multi-model ensemble mean uniform rise, making a total of eleven scenarios.

\subsubsection{Magnitude of rise and spatial variations}

In the 2090 s temperature rise with respect to $1961-1990$, ranges from $2.3^{\circ} \mathrm{C}$ to 3.7 ${ }^{\circ} \mathrm{C}$ (see Table 1), with an ensemble mean rise of $2.9^{\circ} \mathrm{C}$. Sea-level rise ranges from $0.29 \mathrm{~m}$ to $0.53 \mathrm{~m}$ (Figure 1 ), with an ensemble mean of $0.36 \mathrm{~m}$ (similar to the median of the AR4 projections). Spatial distribution of sea-level rise is shown in Figure 2. GFDL-CM2.0 has limited spatial variation compared with other models and also the lowest rise in sea levels (Figure 2a). Conversely, GISS-ER (Figure 2d) reports the highest rise in sea levels (but the lowest rise in temperatures) and has the largest spatial variations, particuarly in the Arctic Ocean. MIROC 3.2 (medres) (Figure 2e) projects higher than its mean sea-level rise around coasts of south and south-east Asia, and lower rises in the Mediterranean. For the ensemble mean pattern (Figure $2 \mathrm{j}$ ), higher than average rise is projected for northern polar regions, whilst lower than average sea-level rise is projected for southern polar regions.

The extent of spatial variations can be compared against the mean sea-level rise (Figure 3). The $\mathrm{x}$-axis represents the range of sea-level rise for each of the $6725^{\circ}$ $x 5^{\circ}$ land-sea grid cells used in DIVA with respect to the mean sea-level rise (e.g. for the ensemble mean scenario, the lowest rise a cell experiences in the 2090s is $0.07 \mathrm{~m}$, the mean rise of all cells is $0.40 \mathrm{~m}$, and the maximum rise a cell projects is $0.77 \mathrm{~m}$. This provides a range of $0.84 \mathrm{~m}$, and a ratio to the mean sea-level rise 
of 2.1). The y-axis represents global mean sea-level rise. The magnitude of sealevel rise slightly differs from Figure 1 as only the land based cells which affect impacts were calculated. Six out of the nine patterned scenarios, plus the ensemble mean, exhibit a range of sea-level rise around twice that of their global mean value. For the patterned ensemble mean, the standard deviation of each cell's magnitude of sea-level rise is $33 \%$ of the mean value. The other six models are similar or lower. However, for the three remaining models, (GISS-ER, GISSEH and MIROC 3.2 (medres)) for which there is a higher range in sea-level rise, the standard deviation is much larger than $33 \%$, or in excess of its mean, indicating large regional extremes. Lowe and Gregory (2006), found average standard deviations of sea-level rise away from the mean of $40 \%$, but regional differences in excess of 100\%. Hence for GISS-ER, GISS-EH and MIROC 3.2 (medres) large spatial variations could potentially have a large influence on global and regional impacts.

Impacts are derived from relative sea-level rise (i.e. eustatic changes in sea-level plus local land level). Table 2 illustrates percentage change between the patterned and uniform ensemble mean relative sea-level rise, including regional variations. Globally, uniform relative sea-level rise is $16 \%$ less than the patterned mean relative sea-level rise. There are large regional variations, particularly for the Mediterranean. The coasts of the C.I.S, East Asia, North America Atlantic coast and North and West Europe coasts, indicate lower uniform relative sea-level rise compared with a patterned rise.

\subsection{Socio-economic scenarios}

The SRES A1B socio-economic scenario (Nakicenovic and Swart 2000) was used as input into the coastal model, specifically changes in population and gross domestic product. Global population grows to mid century, before gently declining, whilst gross domestic product increases throughout the century. 


\section{Impacts}

Table 1 shows a summary of the results (for full results, see Supplementary Material). Regional variations via percentage changes are shown in Table 2 for the patterned and uniform ensemble mean scenarios. Positive values indicate impacts are greater under a uniform scenario rather than a patterned scenario.

\subsection{Coastal wetland loss}

Wetland loss varies between $243 \times 10^{3} \mathrm{~km}^{2}$ and $311 \times 10^{3} \mathrm{~km}^{2}$ by the 2090 s (Figure 5a), with a greater spread of results as time progresses. Broadly, the greatest wetland loss results from models with the highest sea-level rise. For most of the models (excluding GISS-ER and MIROC 3.2 (medres)), there is as close relationship between mean sea-level rise and total wetland loss. (Figure 5b). Thus global wetland loss has a low sensitivity to the spatial pattern. The two remaining models (GISS-ER and MIROC 3.2 (medres)) indicate lower than average loss compared with the mean sea-level rise due to high sea-level rises in northern latitudes. This is further complicated by warming temperatures leading to coastal ice melt and permafrost melt (Burkett and Kusler 2000).

Global losses from the patterned ensemble mean and uniform ensemble mean are similar throughout the century, differing by $3 \%$ in the long time term (Table 2). Larger differences are found around the Mediterranean, coasts of the CIS, small southern Atlantic islands and the North American Atlantic coast.

\subsection{Cumulative dry land loss}

Dry land loss has a wide spread of results (Figure 6a), particularly diverging towards the end of the century, ranging from $4,500 \mathrm{~km}^{2}$ to $7,100 \mathrm{~km}^{2}$ in the $2090 \mathrm{~s}$ (Table 1). Further land loss would be expected through submergence, but is not presented here. Figure $6 \mathrm{~b}$ plots dry land loss against sea-level rise. The relationship between mean sea-level rise and cumulative dry land loss is similar throughout time (except for GISS-ER and MIROC 3.2 (medres)), averaging $17,000 \mathrm{~km}^{2}$ of land loss for each meter of sea-level rise. GISS-ER reports a less than expected land loss compared with the global mean sea-level rise, as much 
higher sea-level rise is found in northern latitudes where there is less erodible land. For MIROC 3.2 (medres), high levels are sea-level rise are found in northwest Europe, north-east America and parts of the Indian Ocean. Whilst the former two are associated with large amounts of land loss, in the Indian Ocean there is less land, so cumulative land loss is much reduced, affecting the results on a global scale.

The greatest difference between the global patterned and uniform ensemble mean sea-level rise occurs in the 2020s (see Table 2), where impacts are $22 \%$ lower with a uniform rise compared with a patterned rise. Relatively, the largest differences are found in the Mediterranean.

\subsection{Expected number of people flooded per year}

Figure 7a illustrates the expected number of people flooded per year throughout time, with changes due to socio-economic conditions and climate change. By the 2040s, the potential number of people flooded starts to diverge, particularly for GISS-EH and MIROC 3.2 (medres). By the 2090s, a maximum of 134 million people ( $1.8 \%$ of the world's population) are projected to be flooded annually corresponding to a rise of $0.48 \mathrm{~m}$ (for MIROC 3.2 (medres)). In MIROC 3.2 (medres), high sea-level rise is anticipated in the Arabian Sea and Bay of Bengal (Figure 2e). These coasts contain large, densely populated low-lying deltas, explaining the high numbers of people who are at risk. MIROC 3.2 (medres) is not the highest possible rise in global mean sea-level, or temperature, so the spatial distribution of sea-level rise is important here.

When the expected number of people flooding per year is plotted against mean sea-level rise (Figure 7b), all models except GISS-ER follow a similar relationship (as GISS-ER projects high levels of sea-level rise in regions of low population density). Excluding GISS-ER as an outlier, the greatest range of the expect number of people flooded between models for the same sea-level rise is $40 \%$ (at $30 \mathrm{~cm}$ of rise). As this occurs between 2065 and 2075, it is mostly attributable to the spatial pattern, rather than changes in population density. Hence a spatial pattern of sea-level rise adds greater variability and uncertainty to the 
number of people expected to be flooded per year, particularly over long time scales, compared with the previous two impact parameters assessed. This is because population growth is time dependent, and as sea levels rise at different rates, exposed population differs for each time step.

There is a close relationship in the expected number of people flooded per year between the global patterned ensemble mean and the uniform ensemble mean scenarios with a maximum of a 9\% difference in the long term (Table 2). Larger regional differences particularly occur in the Mediterranean and coast of the CIS, rather than the densely populated regions of east and south-east Asia.

\section{Discussion}

For seven out of nine patterned scenarios of sea-level rise (see Figure 3), global mean impacts increase proportionally to global mean sea-level (the exceptions being GISS-ER and MIROC 3.2 (medres) as they have a greater range and geographical distribution of sea-level rise). Except for land loss in the 2020s, impacts varied less than $15 \%$ when comparing the global patterned and uniform ensemble mean sea-level rise. The impact parameter least sensitive was wetland loss as large areas of wetlands are expected to be lost for even a small rise in sea levels and therefore at longer timescales there is less sensitivity. Hence, over longer timescales, these smaller sensitivities are less well noticed. Land loss per centimeter of sea-level rise also has a close range of results as the pattern of sealevel rise is the main influence. The expected number of people flooded per year have the greatest spread of results as more people are affected due to topographical reasons, despite a globally decreasing population (i.e. sea-level change is more critical where there is densely populated coastal zones). Furthermore, as the global population is time dependent, this adds additional uncertainty compared with the other parameters investigated. Therefore patterns are important where sensitivity to sea-level rise increases throughout time, and where multiple variables influence output.

For impacts, GISS-ER was frequently the outlier model as large rises occurred in northern latitudes where there is less land and lower population density, therefore 
underestimating impacts with respect to the magnitude of global mean sea-level rise. MIROC 3.2 (medres) (Figure 2e) indicates widespread variations around east African, south and south-east Asia coasts. The latter two regions coincide with low-lying land and population densities, and so impacts are highly sensitive to sea-level rise. Hence applying a uniform value of sea-level rise is not suitable for every parameter, time step or region.

Results from this study suggest that coastal impact studies based on globally uniform mean sea-level rise scenarios (e.g. Nicholls et al. 2010, 2011) are robust for headline numbers and provide a good first estimate. However, in regional analyses (e.g. Nicholls et al. 2010) impacts are more overestimated than underestimated when using a uniform rise compared with a patterned rise, as higher rises tend to occur in extreme northern or southern latitudes where there is less land. Semi-enclosed seas, particularly the Mediterranean have large regional differences in impacts compared with the global mean. Therefore using a uniform sea-level rise can over estimate impacts by at least one order of magnitude (Table 2). Evidence of past trends (e.g. Wöppelmann and Marcos 2012) indicate lower rises of sea-level on the Mediterranean semi-enclosed coast, compared with the exposed Atlantic Iberian coast. For other semi-enclosed seas such as the Baltic, change in seasonal ice melt and precipitation have a large influence on sea levels. Thus from a modeling perspective, further research is encouraged into regional projections where a uniform sea-level rise is a poor representation, particularly where there are low-lying populated coastlines.

Many other factors influence impacts (e.g. adaptation level, coastward migration) that cannot be fully accounted for in models due to lack of reliable, consistent data and models, adding uncertainty to impact projections. Global coastal and river flooding research (assuming no flood defences) based on (a) changes in land use and (b) population change by Jongman et al. (2012) found both methods had similar levels and trends in global exposure, but large variations in regional distribution due to differences in measuring population density and urbanisation. Hinkel et al (submitted) analysed a range of adaptation strategies within the DIVA model. They found that impacts could be two to three times more sensitive to the type of adaptation employed compared with socio-economic and climate change 
scenarios. These publications illustrate that population change and adaptation can be at least or as important as sea-level when assessing damages at a regional scale, even if global studies produce similar values. Further work to better identify impacts and improve potential adaptation to impacts should give greater consideration into socio-economic change, working at regional levels.

\section{Conclusions}

Global and regional variations of nine patterned sea-level rise scenarios (plus the uniform and patterned ensemble mean) were analysed to determine the influence of the pattern on three impact metrics (coastal wetland loss, dry land loss due to erosion and the expected number of people flooded per year), using an A1B climate and socio-economic scenario and assuming no upgrade in protection.

For seven out of nine models, impacts occurred at a proportional (although nonlinear) rate to the magnitude of global sea-level rise. As analyses becomes more spatially discrete, deviations in the impacts are expected, so at regional scales, patterns increase the range of expected impacts. For two models, very high magnitudes of sea-level rise in polar or less populated regions resulted in fewer impacts than expected compared with other models which had a similar magnitude of sea-level rise and less geographical variation in the pattern. Due to large populations, and in places a reduced ability to respond or adapt for financial reasons, impacts are potentially high in the south, south-east and east Asia regions. Therefore in these regions, knowledge of past local sea-level rise (e.g. through tide gauge records) and future sea-level rise is highly important.

Many post-AR4 sea-level rise scenarios, including those which project in excess of $1 \mathrm{~m}$ rise per century (see Nicholls et al. 2011), only provide a uniform rise in sea-level. These results indicate that to assess impacts on a global scale, the spatial variability of sea-level rise is of lesser importance than the overall magnitude of rise. However, for regional analyses, patterns can be important, particularly around semi-enclosed seas, such as the Mediterranean, and also the northern Russian coast. Further modeling research is required to better predict local sea-level rise, particularly for semi-enclosed seas where interaction with 
other parameters, such as freshwater input, influences sea-level rise. Additionally, with the development of glacial isostatic adjustment (GIA) fingerprinting into sealevel rise scenarios (Radić and Hock 2011), more realistic patterns will be developed, and the influence of this on impacts should be assessed. Finally, to better focus long-term research needs, sensitivity into changes in socio-economic conditions and adaptation measures could be explored, particularly around coasts where there are large variations and uncertainties associated with sea-level rise.

Acknowledgements: Brown and Nicholls were supported by the UK Natural Environment Research Council (NERC), under the QUEST programme (grant number NE/E001882/1). Lowe was supported by the AVOID programme (DECC and Defra) under contract GA0215

For the sea-level rise patterns we acknowledge the international modelling groups for providing their data for analysis, the Program for Climate Model Diagnosis and Intercomparison (PCMDI) for collecting and archiving the model data, the JSC/CLIVAR Working Group on Coupled Modelling (WGCM) and their Coupled Model Intercomparison Project (CMIP) and Climate Simulation Panel for organising the model data analysis activity, and the IPCC WG1 TSU for technical support. The IPCC Data Archive at Lawrence Livermore National Laboratory is supported by the Office of Science, US Department of Energy.

We thank Anne Pardaens and Ivan Haigh for comments and assistance in constructing the sealevel rise scenarios. 


\section{References}

Burkett V, Kusler J (2000) Climate change: Potential impacts and interactions in wetlands of the United States. J Am Waterw Resour Assoc 32 (2):313-320

Center for International Earth Science Information Network (CIESIN), Columbia University, International Food Policy Research Institute (IFPRI), World Resources Institute (WRI) (2000) Gridded Population of the World (GPW), Version 2. Palisades. CIESIN, New York

Gregory J, Huybrechts P (2006) Ice-sheet contributions to future sea-level change. Philos Trans R Soc Lond A 364:1709-1731. DOI:1710.1098/rsta.2006.1796

Hinkel J, Klein RJT (2009) Integrating knowledge to assess coastal vulnerability to sea-level rise: The development of the DIVA tool. Glob Environ Change 19:384-395. DOI:310.1016/j.gloenvcha.2009.1003.1002

Hinkel J, Lincke D, Vafeidis AT, Perrette M, Nicholls RJ, Tol RSJ, Marzeion B, Fettweis X, Levermann A Impact of future sea-level rise of global risk coastal floods. Submitted to Proc Natl Acad Sci USA.

Hinkel J, Nicholls RJ, Tol RSJ, Boot G, Vafeidis A, Wang Z, Hamilton J, Klein R A global analysis of erosion of sandy beaches and sea-level rise: An application of DIVA. Accepted by Glob Planet Change

Jongman B, Ward PJ, Aerts JCJH (2012) Global exposure to river and coastal flooding: Long term trends and changes. Glob Env Change 22 (4):823-835.

DOI:10.1016/j.gloenvcha.2012.07.004

Lowe JA, Gregory JM (2006) Understanding projections of sea level rise in a Hadley Centre coupled climate model. J Geophys Res, C, Oceans 111 (C11):1-12

Manning MR, Edmonds J, Emori S, Grubler A, Hibbard K, Joos F, Kainuma M, Keeling RF, Kram T, Manning AC, Meinshausen M, Moss R, Nakicenovic N, Riahi K, Rose SK, Smith S, Swart R, van Vuuren DP (2010) Misreprentation of the IPCC $\mathrm{CO}_{2}$ emission scenarios. Nature Geosci 3 (6):376-377

McFadden L, Spencer T, Nicholls RJ (2007) Broad-scale modelling of coastal wetlands: what is required? Hydrobiolgica 577: 5-15

Meehl GA, Stocker TF, Collins WD, Friedlingstein P, Gaye AT, Gregory JM, Kitoh A, Knutti R, Murphy JM, Noda A, Raper SCB, Watterson IG, Weaver AJ, Zhao Z-C (2007) Global climate projections. In: Solomon S, Qin D, Manning M et al. (eds) Climate change 2007: The physical science basis. Contribution of Working Group I to the Fourth Assessment Report of the Intergovernmental Panel on Climate Change. Cambridge University Press, Cambridge, UK, pp 433-497

Nakicenovic N, Swart R (eds) (2000). Emissions scenarios. Special report of the Intergovernmental Panel on Climate Change. Cambridge University Press, Cambridge, UK

Nicholls RJ (2004) Coastal flooding and wetland loss in the 21st century: Changes under the SRES climate and socio-economic scenarios. Glob Environ Change 14 (1):69-86

Nicholls RJ, Cazenave A (2010) Sea-level rise and its impact on coastal zones. Science 328 (5985): 1717-1520. DOI:10.1110.1126/science.1185782

Nicholls RJ, Brown S, Hanson S, Hinkel J (2010) Economics of coastal zone adaptation to climate change. The World Bank, Washington, USA.

http://climatechange.worldbank.org/sites/default/files/documents/DCCDP_10_CoastalZo neAdaptation.pdf Accessed July 2013

Nicholls RJ, Marinova N, Lowe JA, Brown S, Vellinga P, de Gusmão D, Hinkel J, Tol RSJ (2011) Sea-level rise and its possible impacts given a 'beyond $4^{\circ} \mathrm{C}$ world' in the twenty-first century. Philos Trans R Soc A 369:161-181. DOI: 10.1098/rsta.2010.0291

Nicholls RJ, Wong PP, Burkett VR, Codignotto JO, Hay JE, McLean RF, Ragoonaden S, Woodroffe CD (2007) Coastal systems and low-lying areas. In: Parry ML, Canziani OF, 
Palutikof JP, van der Linden PJ, Hanson CE (eds) Climate change 2007: Impacts, adaptation and vulnerability. Contribution of Working Group II to the Fourth Assessment Report of the Intergovernmental Panel on Climate Change. Cambridge University Press, Cambridge, UK, pp 315-357

Osborn $\mathrm{T}$ et al. Climate scenarios for the assessment of the global-scale impacts of climate change. Submitted to Climatic Change (this special issue)

Pardaens AK, Lowe JA, Brown S, Nicholls RJ, de Gusmão D (2011) Sea-level rise and impacts projections under a future scenario with large greenhouse gas emission reductions. Geophys Res Lett 38:L12604. DOI:12610.11029/12011GL047678

Peltier WR (2000a) Global glacial isostatic adjustment and modern instrumental records of relative sea level history. In: Douglas BC, Kearny MS, Leatherman SP (eds) Sea level rise; history and consequences. Academic Press, San Diego, pp 65-95

Peltier WR (2000b) Ice4g (vm2) glacial isostatic adjustment corrections. In: Douglas BC, Kearny MS, Leatherman SP (eds) Sea level rise; history and consequences. Academic Press, San Diego, on CD

Radić V, Hock R (2011) Regionally differentiated contribution of mountain glaciers and ice caps to future sea-level rise. Nature Geosci 4:91-94. DOI:10.1038/ngeo1052

Raper SCB, Cubasch U (1996) Emulation of the results from a coupled general circulation model using a simple climate model. Geophys Res Lett 23:1107-1110

Vafeidis AT, Nicholls RJ, McFadden L, Tol RSJ, Hinkel J, Spencer T, Grashoff PS, Boot G, Klein R (2008) A new global coastal database for impact and vulnerability analysis to sea-level rise. J Coast Res 24:917-924. DOI:910.2112/2106-0725.2111

van Goor M, Zitman T, Wang Z, Stive M (2003) Impact of sea-level rise on the morphological equilibrium state of tidal inlets. Marin Geol 202:211-227. DOI:210.1016/S00253227(1003):00262-00267

van Vuuren DP, Lucas PL, Hilderink H (2007) Downscaling drivers of global environmental change: Enabling use of global SRES scenarios at the national and grid scales. Glob Environ Change 17:114-130

Wöppelmann, G. Marcos M (2012) Coastal sea level rise in southern Europe and the non climate contribution of vertical land motion J Geophys Res: Oceans DOI: 10.1029/2011JC007469

Zhang K, Douglas B, Leatherman S (2004) Global warming and coastal erosion. Clim Change $64: 41-58$ 


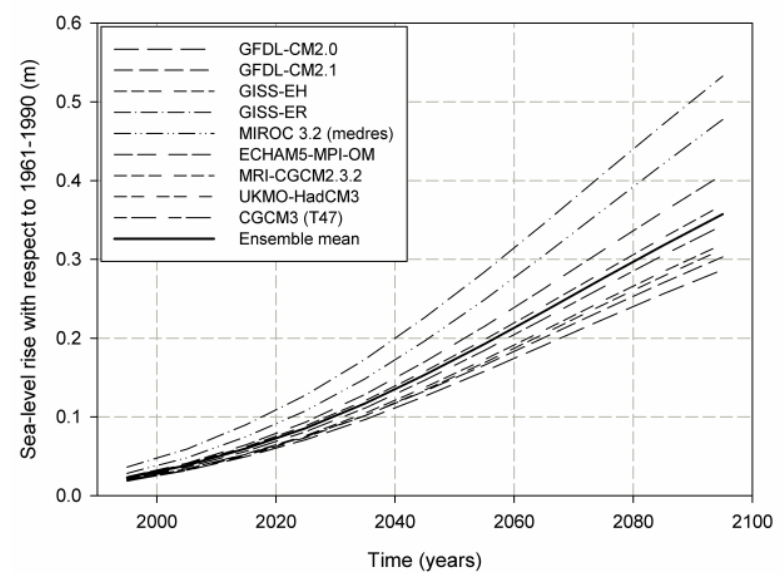

Figure 1 Global mean sea-level rise for the nine patterned CMIP3 models analysed and the multimodel ensemble mean sea-level rise. Data is with respect to 1961-1990 
a) GFDL-CM2.0
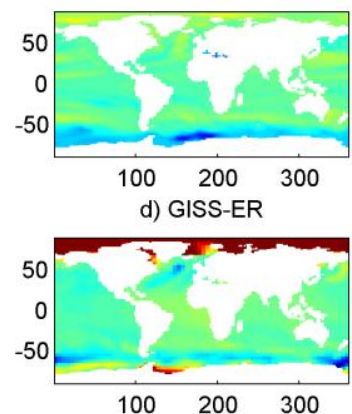

g) MRI-CGCM2.3.2

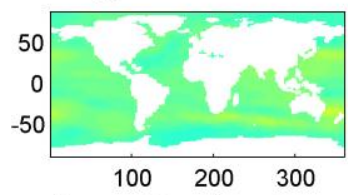

j) ensemble patterned mean

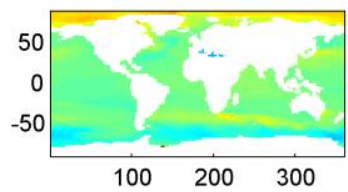

b) GFDL-CM2.1

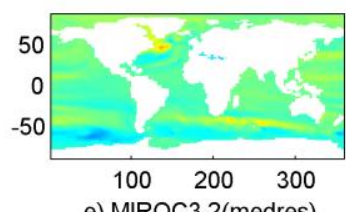

e) MIROC3.2(medres)

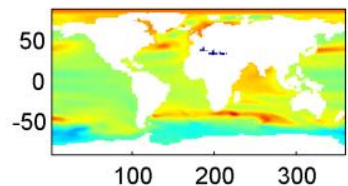

h) UKMO-HadCM3

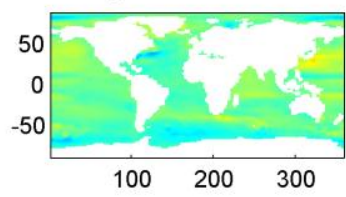

Sea-level rise in the 2090 s with respect to $1961-1990$ (m)

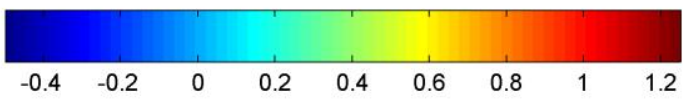

Figure 2 Projections for the nine patterned CMIP3 models in the 2090s and the multi-model patterned ensemble mean sea-level rise, with respect to 1961-1990 


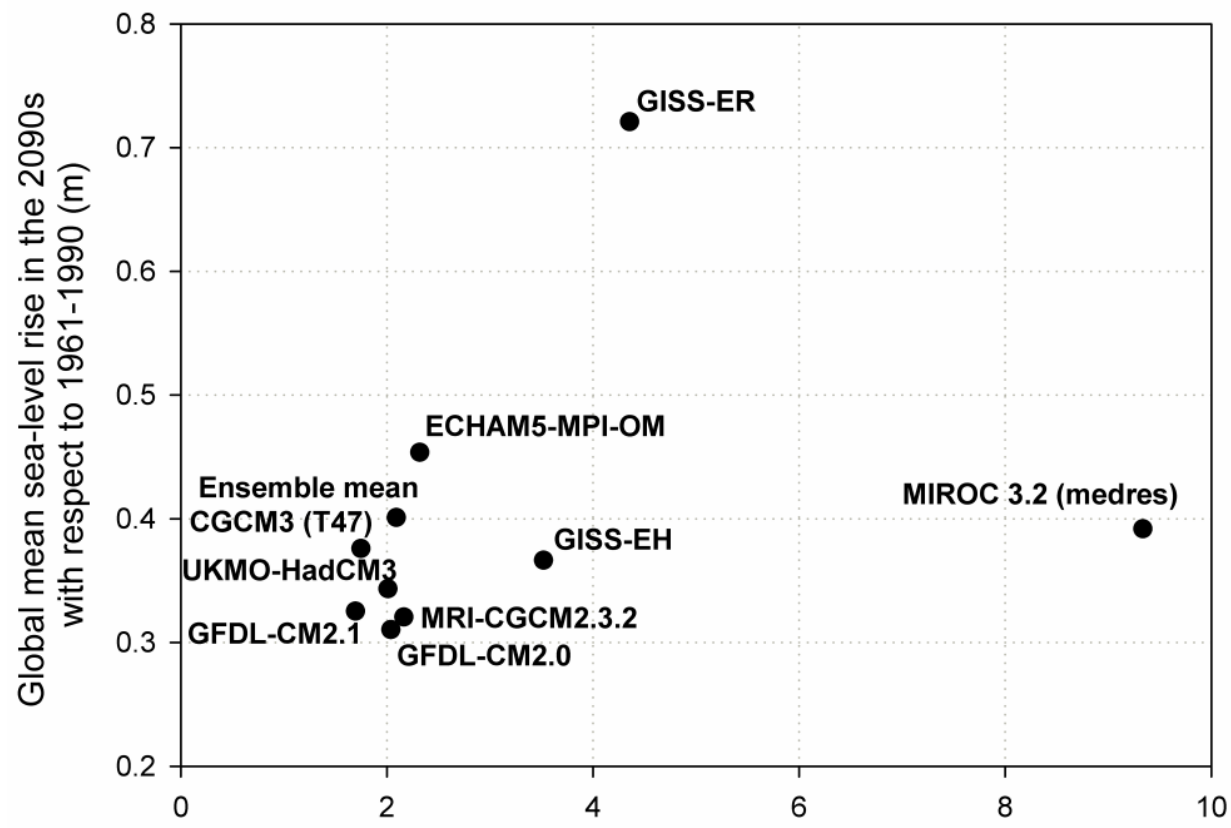

Range in regional sea-level rise divided by the global mean sea-level rise

Figure 3 Relationship between the range of regional sea-level rise within a patterned scenario against the global mean sea-level rise. Data extracted from the 2090s. 


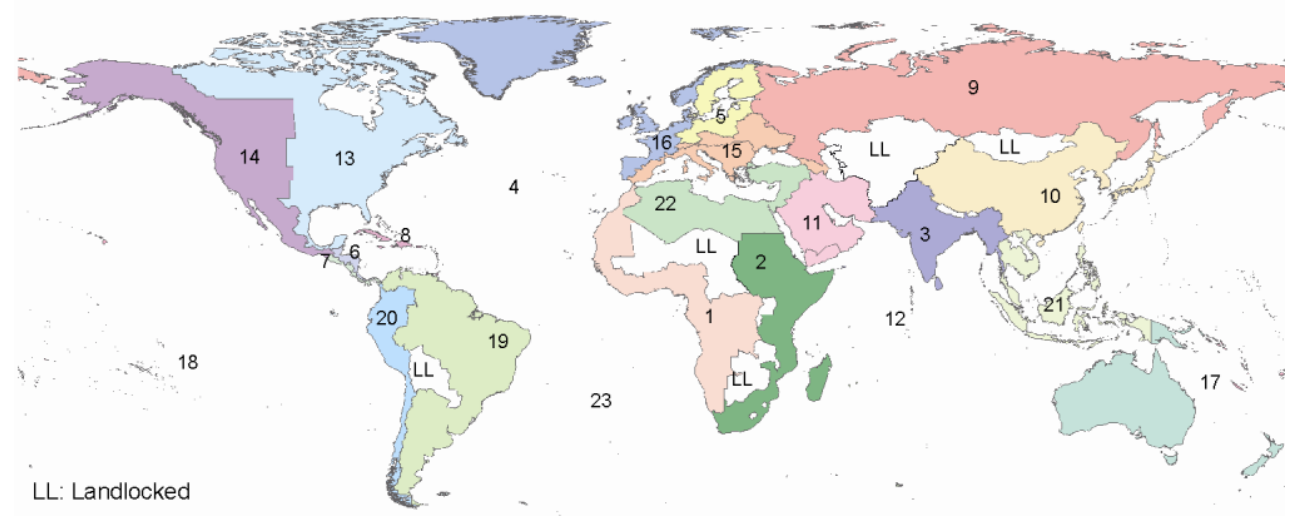

Figure 4 The global regions reported in Table 2 

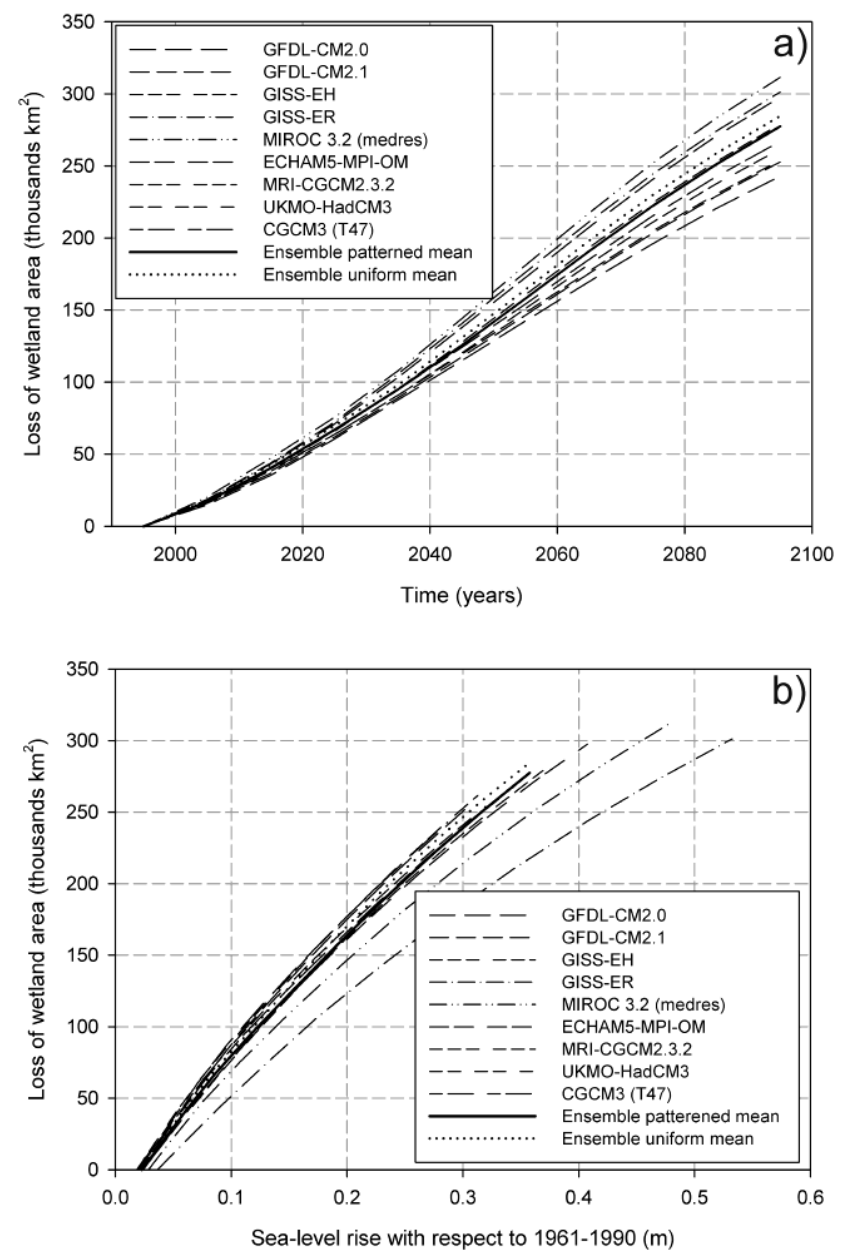

Figure 5 Net global coastal wetland loss with respect to 1961-1990 for different climate models, plotted against a) time; b) global mean sea-level rise 

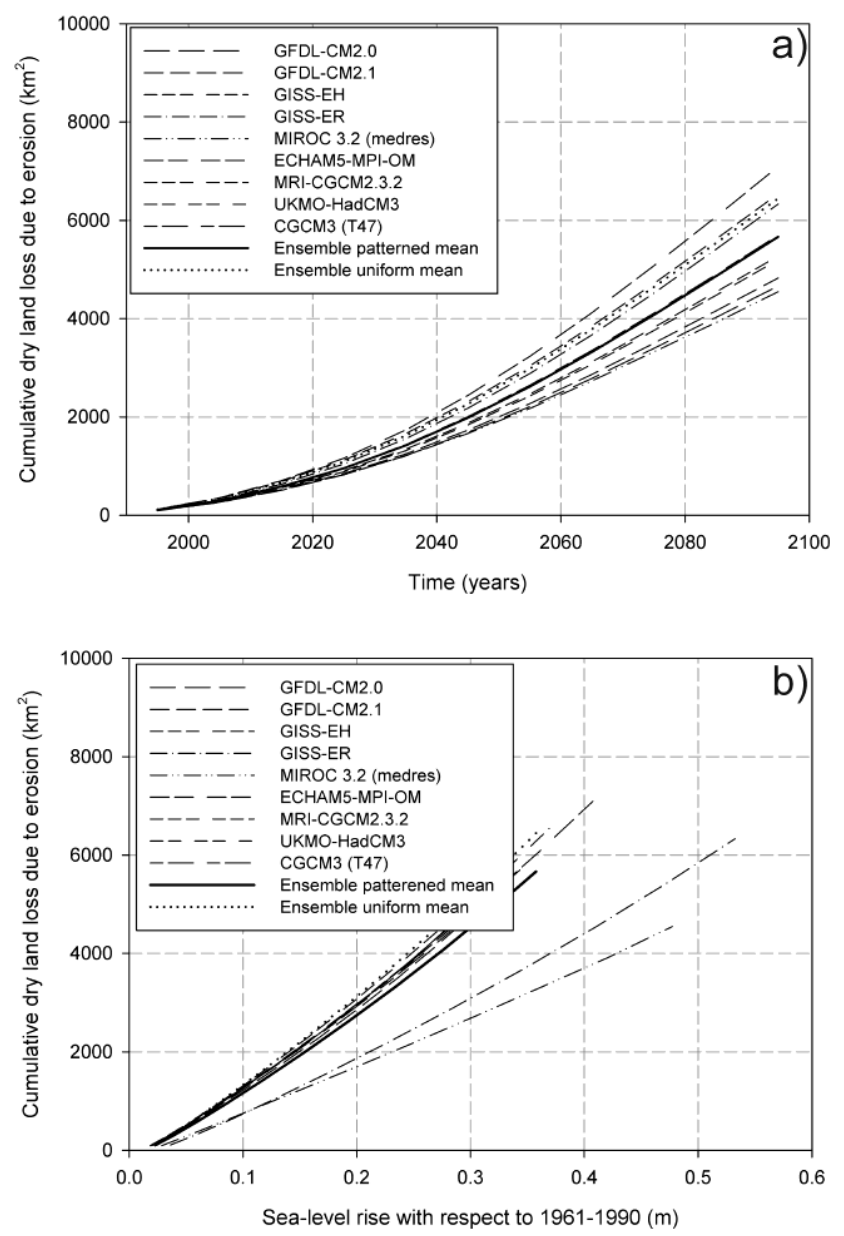

Figure 6 Cumulative dry land loss due to erosion with respect to 1961-1990 for different climate models plotted against a) time; b) global mean sea-level rise 

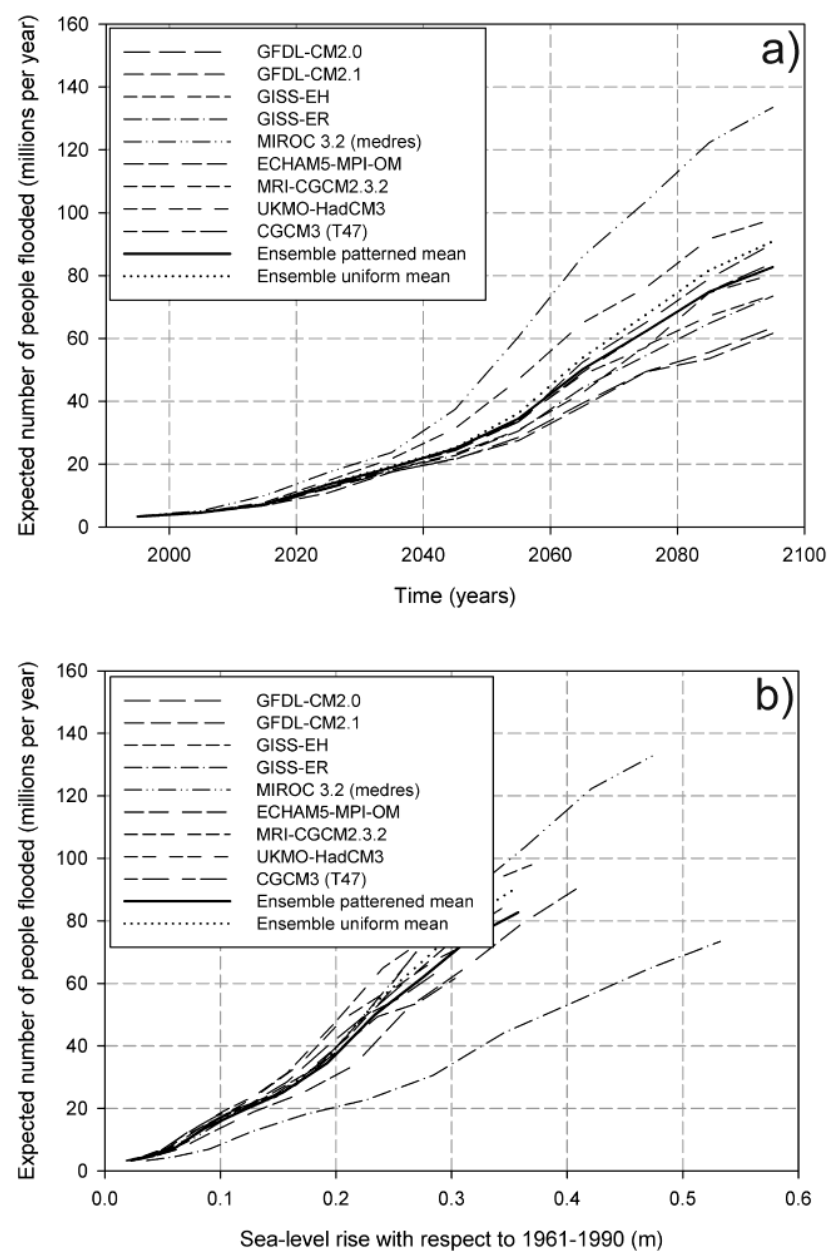

Figure 7 Expected number of people flooded per year (with A1B socio-economic scenario) with respect to 1961-1990 for different climate models plotted against a) time; b) global mean sea-level rise 
Table 1 Summary of results from the 2090s with respect to 1961-1990, based on the nine patterned scenarios and associated impacts. Minimum values are underlined in bold, whilst maximum values are in italic in bold.

\begin{tabular}{|c|c|c|c|c|c|}
\hline Model & $\begin{array}{l}\text { Temperature } \\
\text { rise } \\
{ }^{\circ} \mathrm{C} \\
\end{array}$ & $\begin{array}{l}\text { Sea-level rise } \\
\mathrm{m}\end{array}$ & $\begin{array}{l}\text { Net wetland } \\
\text { loss } \\
10^{6} \mathrm{~km}^{2}\end{array}$ & $\begin{array}{l}\text { Cumulative dry } \\
\text { land loss due to } \\
\text { erosion } \\
\mathrm{km}^{2}\end{array}$ & $\begin{array}{l}\text { Expected } \\
\text { number of } \\
\text { people flooded } \\
\text { per year } \\
\text { millions/yr }\end{array}$ \\
\hline GFDL-CM2.0 & 2.5 & $\underline{0.29}$ & $\underline{243}$ & 4663 & 63 \\
\hline GFDL-CM2.1 & 2.3 & 0.30 & $\overline{253}$ & 4827 & $\underline{62}$ \\
\hline GISS-EH & 2.7 & 0.37 & 279 & 6538 & 98 \\
\hline MIROC 3.2 (medres) & 3.5 & 0.48 & 311 & $\underline{4549}$ & 134 \\
\hline ECHAM5-MPI-OM & 3.7 & 0.41 & 298 & 7093 & 90 \\
\hline MRI-CGCM2.3.2 & 3.0 & 0.32 & 254 & 5274 & 74 \\
\hline UKMO-HadCM3 & 3.3 & 0.31 & 262 & 5196 & 80 \\
\hline CGCM3 (T47) & 3.1 & 0.34 & 267 & 5698 & 84 \\
\hline Patterned ensemble mean & 2.9 & 0.36 & 277 & 5665 & 83 \\
\hline
\end{tabular}


Table 2 Percentage change in relative sea-level rise and the impact metrics for the multi-model uniform and patterned ensemble mean, based on global regions (defined in Figure 4). Data is based on thirty-year means. Negative values indicates the uniform rise underestimates impacts compared with a patterned sea-level rise

\begin{tabular}{|c|c|c|c|c|c|c|c|c|c|c|c|c|c|}
\hline & \multicolumn{3}{|c|}{$\begin{array}{l}\text { Relative } \\
\text { sea-level } \\
\text { rise }\end{array}$} & & $\begin{array}{l}\text { bast } \\
\text { etlan } \\
\text { loss }\end{array}$ & & $\begin{array}{l}\text { Dry } \\
\text { loss } \\
\text { to er }\end{array}$ & $\begin{array}{l}\text { lan } \\
\text { s du } \\
\text { rosic }\end{array}$ & & \multicolumn{3}{|c|}{$\begin{array}{c}\text { Expected } \\
\text { number } \\
\text { of people } \\
\text { flooded } \\
\text { per year } \\
\end{array}$} & \\
\hline & 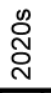 & $\begin{array}{l}\infty \\
\text { Dे } \\
\text { Dे }\end{array}$ & $\begin{array}{l}\infty \\
\text { D } \\
\text { Dે } \\
\text { N }\end{array}$ & ণั & $\begin{array}{l}\infty \\
\text { Dે } \\
\text { Dे }\end{array}$ & $\begin{array}{l}\text { Oొ } \\
\infty \\
\text { ర్ }\end{array}$ & 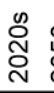 & & : & & & $\begin{array}{l}\infty \\
D^{\infty} \\
0 \\
\text { D }\end{array}$ & \\
\hline 1 Africa Atlantic Ocean & & & & & & & $\mathbf{X}$ & & & & & & \\
\hline 2 Africa Indian Ocean & & & & & & & $\mathbf{X}$ & & & & & & $>1000 \%$ \\
\hline 3 Asia Indian Ocean & & & & & & $\mathbf{X}$ & $\mathbf{X}$ & & & & & & $100-999.9 \%$ \\
\hline 4 Atlantic Ocean small islands & & & & $\mathbf{X}$ & $\mathbf{X}$ & & $\mathbf{X}$ & & & & & & $50-99.9 \%$ \\
\hline 5 Baltic Sea & & $\mathbf{x}$ & $\mathbf{x}$ & $\mathbf{X}$ & $\mathbf{X}$ & $\mathbf{X}$ & $\mathbf{x}$ & \begin{tabular}{l|l}
$\mathbf{X}$ & 2 \\
\end{tabular} & $\mathbf{X}$ & & & & $10-49.9 \%$ \\
\hline 6 Central America Atlantic & & & & & $\mathbf{X}$ & & $\mathbf{X}$ & & & & & & $0-9.9 \%$ \\
\hline 7 Central America Pacific & & & & & & & $\mathbf{X}$ & & & & & & Indicates \\
\hline 8 Caribbean islands & & & & & & & $\overline{\mathbf{X}}$ & & & & & & $\mathbf{X}$ negative \\
\hline 9 Coasts of the C.I.S. & $\mathbf{X}$ & $\mathbf{X}$ & $\bar{X}$ & & & & $\mathbf{X}$ & & & & & & values \\
\hline 10 East Asia & $\mathbf{X}$ & $\mathbf{X}$ & $\mathbf{X}$ & $\mathbf{X}$ & $\mathbf{X}$ & $\mathbf{X}$ & $\mathbf{x}$ & $\mathbf{X}$ & $\mathbf{x}$ & $\mathbf{X}$ & $\mathbf{X}$ & $\mathbf{X}$ & Indicates \\
\hline 11 Gulf States & & & & $\mathbf{X}$ & & & $\mathbf{x}$ & $\mathbf{X}$ & $\mathbf{X}$ & & & & 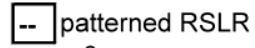 \\
\hline 12 Indian Ocean small islands & & & & & & & $\mathbf{x}$ & & & & & & $=0$ \\
\hline 13 North America Atlantic & $\mathbf{X}$ & $\mathbf{x}$ & $\bar{x}$ & $\mathbf{X}$ & $\mathbf{x}$ & $\mathbf{X}$ & $\mathbf{X}$ & & & & & & \\
\hline 14 North America Pacific & & & & & & & $\mathbf{X}$ & & & & & & \\
\hline 15 Northern Mediterranean & - & & & & & & & & & & & & \\
\hline 16 North and West Europe & $\mathbf{X}$ & $\mathbf{X}$ & $\mathbf{x}$ & $\mathbf{X}$ & $\mathbf{X}$ & & $\mathbf{X}$ & & & $\mathbf{X}$ & & & \\
\hline 17 Pacific Ocean large islands & & & & & & & $\mathbf{X}$ & & & & & $\mathbf{X}$ & \\
\hline 18 Pacific Ocean small islands & & & & & & & $\overline{\mathbf{X}}$ & & & & & & \\
\hline 19 South America Atlantic & & & & & & & $\mathbf{X}$ & & & & & & \\
\hline 20 South America Pacific & & & & & & & $\mathbf{X}$ & & & & & & \\
\hline 21 South-east Asia & & & & & & & $\mathbf{X}$ & & & & & & \\
\hline 22 Southern Mediterranean & - & & & & & & & & & & & & \\
\hline 23 Southern Atlantic small islands & & & & & & & & & & & & & \\
\hline Global & $\mathbf{X}$ & $\mathbf{X}$ & $\mathbf{x}$ & & & & $\mathbf{x}$ & & & & & & \\
\hline
\end{tabular}

